\title{
Identifying Opportunities to Conserve Farm Ponds on Private Lands: Integration of Social, Ecological, and Historical Data
}

\author{
Timothy M. Swartz ${ }^{1,2, * \mathbb{C}}$, Jaime J. Coon ${ }^{2}{ }^{\mathbb{D}}$, Jenna R. Mattes ${ }^{2}$ and James R. Miller ${ }^{2,3}$ \\ 1 Center for Biodiversity, Department of Biology, Temple University, Philadelphia, PA 19140, USA \\ 2 Department of Natural Resources and Environmental Sciences, University of Illinois at Urbana-Champaign, \\ Urbana, IL 61820, USA \\ 3 Program in Ecology, Evolution, and Conservation Biology, University of Illinois at Urbana-Champaign, \\ Urbana, IL 61820, USA \\ * Correspondence: timothy.swartz@temple.edu
}

Received: 30 June 2019; Accepted: 21 August 2019; Published: 23 August 2019

check for updates

\begin{abstract}
In some landscapes, effective conservation of wildlife habitat requires extending beyond the boundaries of reserves and addressing stewardship of private lands. This approach could be especially valuable for the conservation of farm ponds, which are abundant and serve key agricultural functions on private lands. Though farm ponds also provide wildlife habitat, little is known about how they are managed or how values and beliefs of their owners relate to their quality. To address this knowledge gap, we collected data on pond habitat quality and management using historical aerial imagery and high-resolution Google Earth satellite imagery of the Grand River Grasslands of southern Iowa and Northern Missouri. We also collected spatially congruent social data using a mail back survey sent to 456 landowners in the region (32.7\% response rate). We used mixed-effects linear regression to link indicators of habitat quality to the survey results. We found that many ponds were permanent, accessible to cattle, in early successional states, and had little wetland vegetation, indicating a scarcity of suitable habitat for wildlife. At the same time, $35-57 \%$ of survey respondents said they would be willing to change their management to benefit aquatic organisms. Our analyses indicated that higher cover of cattails correlated with ownership by respondents who regarded row crops or income from agriculture as less important and ponds tended to be temporary if owned by respondents who had many ponds. Moving forward, large landowners and those willing to manage their land to benefit wildlife may constitute a core set of future partners for conservation efforts focused on improving pond habitat in the region.
\end{abstract}

Keywords: farm ponds; working landscapes; wildlife habitat; conservation; values and attitudes

\section{Introduction}

Loss of biological communities and the natural habitats that support them is a concerning symptom of agricultural intensification worldwide [1]. While protected areas are a critical tool for halting losses of biodiversity, there is growing evidence that protected areas alone are not sufficient [2,3]. Indeed, protected areas in the United States are scarce in many landscapes that have experienced extensive loss of natural ecosystems, such as the U.S. Corn Belt, where less than $1.80 \%$ of land is protected (compared with $11.22 \%$ nationally; [4]). Successful wildlife conservation in this context requires balancing habitat protection with human enterprise. Addressing this challenge is a strength of the "working landscapes" framework where humans are considered an integral part of the ecosystem, driving both social and ecological processes that impact natural systems in negative and positive ways [5]. 
Though research into the challenges of carrying out habitat conservation in working landscapes has led to many insights e.g., [6,7], the ubiquitous farm ponds that support these agricultural systems are often overlooked. In the central U.S., millions of farm ponds have been constructed in the last century (Figure 1; [8,9]). These ponds can also provide habitat for native wildlife [10,11]. While some research has addressed the role of these ponds in abiotic processes like sediment capture [12] and mercury pollution [8], little is known about their function and quality as wildlife habitat but see [13-15]. Furthermore, most ponds are located on private lands [13] but the drivers underlying the management decisions made by landowners, and the consequences of those behaviors for habitat quality, have not been addressed in the published literature.

(a)

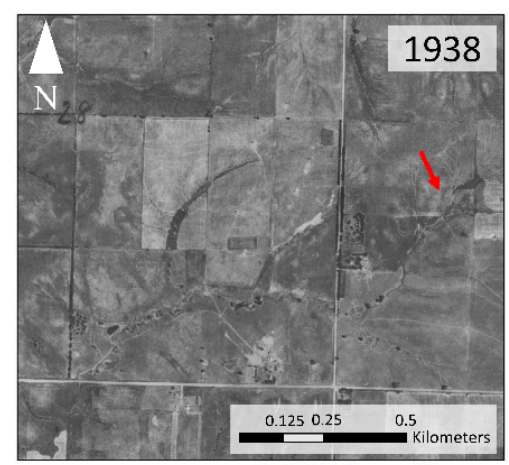

(b)

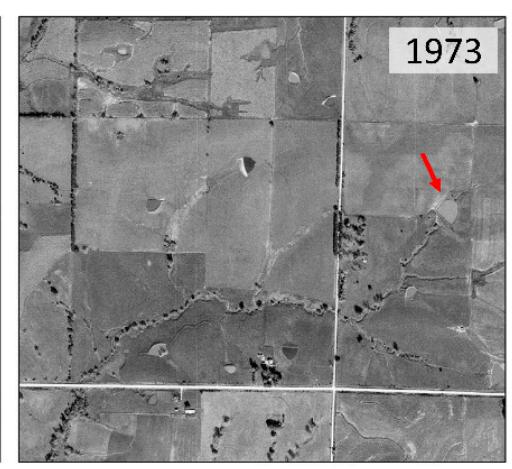

(c)

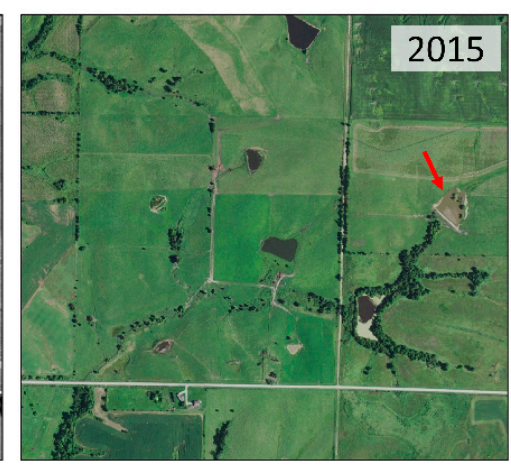

Figure 1. Aerial imagery of farmland in Ringgold County, Iowa depicting the landscape in 1938 (a), 1973 (b), and 2015 (c). Between 1938 and 2015, about nine ponds were constructed in this area. The red arrow indicates a pond that was built after 1938 and then renovated between 1973 and 2015 .

\subsection{Balancing Agricultural and Ecological Functions in Farm Ponds}

Farm ponds are extremely abundant and comprise the majority of lentic habitats available in some parts of the Eastern Great Plains [11]. In this context, conservation of wildlife habitat in ponds must be balanced against their primary agricultural functions of providing water for livestock, mainly cattle (Figure 2a), and capturing soil-laden runoff, thereby preventing erosion (Figure 2b). Managing ponds for these agricultural functions has substantial implications for wildlife. For example, when permitted to have direct access to wetlands, cattle can have profound negative impacts on water quality and vegetation [16,17], yet it is unclear what proportion of ponds currently provide water for livestock and may be impacted. In addition, it is widely recommended that landowners protect wildlife habitat by fencing ponds and provide water to livestock by piping water to a trough below the pond dam (see [18]). However, we are not aware of any studies that have quantified the extent to which landowners comply with these recommendations at a landscape scale. Exploring the distribution of these practices on the landscape could provide key insights into habitat quality of ponds located on private properties.

The second agricultural function of farm ponds—capturing eroding soil—may also be in conflict with habitat conservation. Pond renovation, a process whereby a pond is drained, dredged, and then rebuilt (Figure 3; see [15]), is used to 'reset' pond succession and maintain the ability of ponds to mitigate erosion. Over time, ponds accumulate excessive sediment and lose their capacity to absorb runoff, thus becoming unreliable as livestock water sources. The deep mud that forms around the margins of old ponds also poses a hazard to cattle, which may get stuck and sustain injury or perish [18]. Furthermore, though emergent wetland plants (like cattails [Typha spp.]) can readily colonize pond margins and may provide habitat for wildlife, they are often considered weedy and undesirable [19]. These are just a few of the reasons that landowners may choose to renovate aging ponds. At the same time, succession-driven changes in biotic and abiotic habitat conditions (see [8]) can result in improved habitat quality for native aquatic species of conservation concern, including some amphibians [15]. By renovating ponds, landowners eliminate existing habitat and arrest future habitat development. If 
widespread, renovation activities could have negative impacts on farm pond biodiversity (Swartz and Miller 2019). In central Texas, Berg, et al. [20] found that about one-third of ponds had undergone renovation, but whether this rate is similar in other landscapes is unknown.
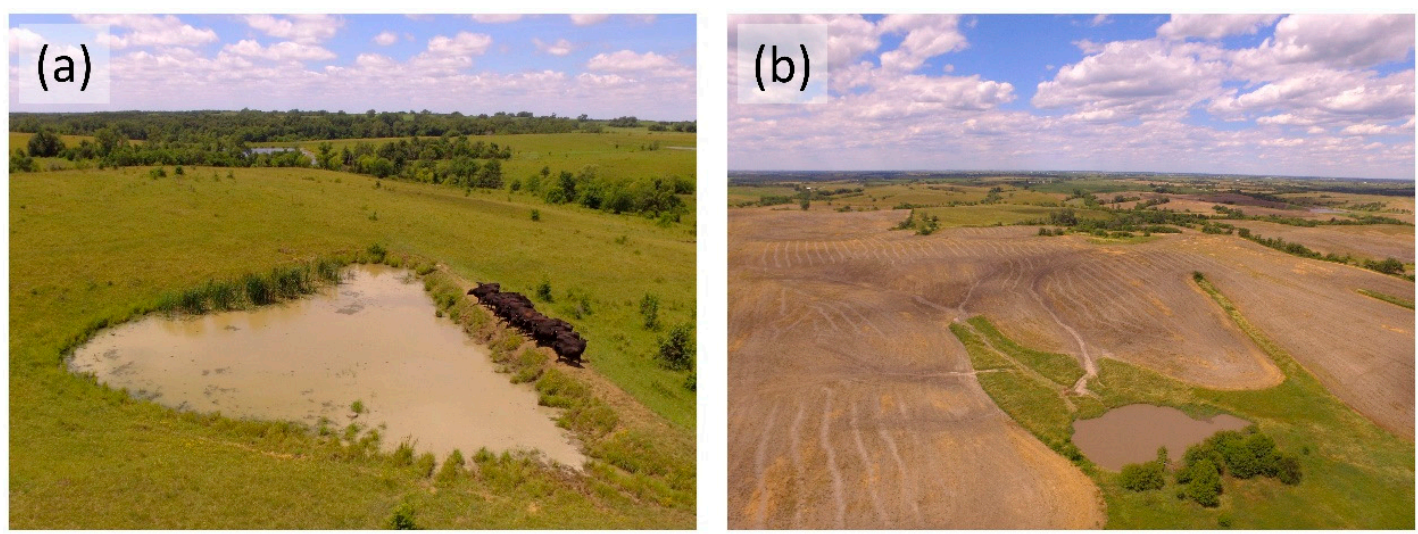

Figure 2. Photographs depicting primary functions of farm ponds in the Eastern Great Plains: (a) Ponds play a vital role in supporting cattle production by providing a reliable water source for livestock. (b) Ponds located on row crop fields are used to mitigate soil erosion by capturing sediment-laden runoff.

(a)

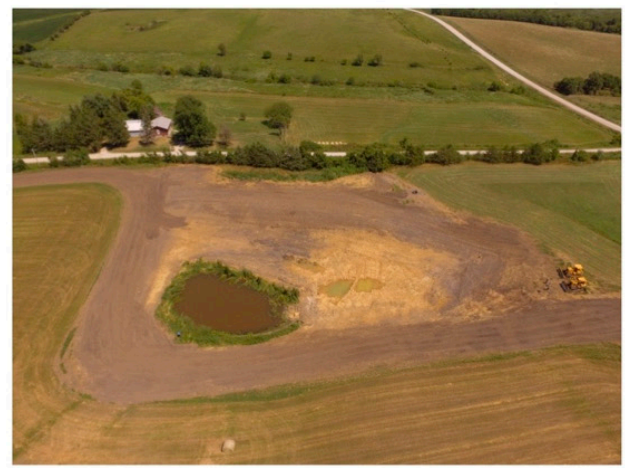

(b)

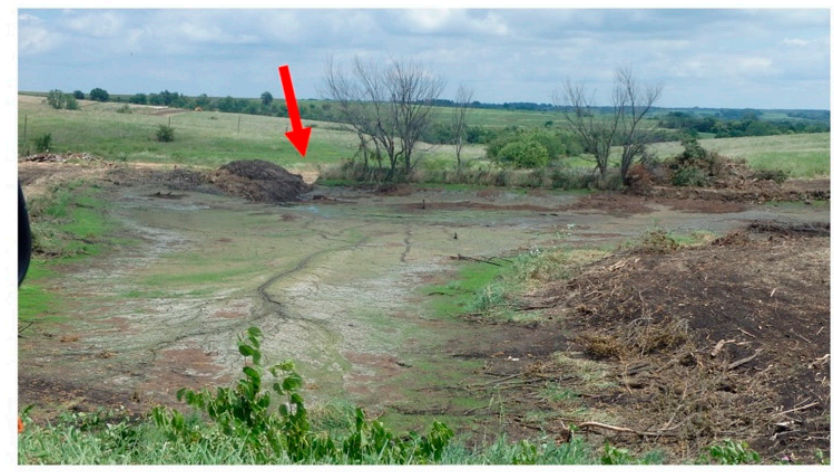

Figure 3. Photographs illustrating possible renovation processes for a pond on parcels where: (a) the lack of suitable sites on the property means that a new pond will be built around an old pond, which will be flooded when the new pond is complete; or (b) the embankment of the pond is breeched (red arrow) and the pond is drained, allowed to dry, and will later be dredged. In both cases, the shallow-water ecosystem that developed over time will be destroyed and replaced by a deep, permanent water pond ecosystem.

\subsection{The Importance of Wildlife Values and Attitudes for Management}

In addition to these key gaps in our knowledge of farm pond management, little is known about how the underlying social drivers relate to patterns of habitat quality and availability. For pondowners that are active agricultural producers, environmental and economic concerns relating to wildlife and agriculture are likely drivers of pond management behavior. A survey of landowners in Texas suggests that most landowners devote little effort to extensive management of their ponds for wildlife [21], but it is unclear how pond maintenance decisions are related to environmental attitudes and values.

Few studies have examined landowner views of rural ponds and the aquatic wildlife they support (but see [22,23]), but research from the field of human dimensions of the environment can provide insight into the decision-making process that leads individuals to adopt certain management behaviors [24]. Values are at the base of decision-making and constitute an individual's core principles for what is important in life. Humans value wildlife and nature for both utilitarian and intrinsic reasons [25], and these values can influence the development of both attitudes and behavior related to the environment [26]. Attitudes are defined as a positive or negative evaluation of an object or 
idea and can include assessments of a particular species or management technique. While other factors like social norms and an individual's ability to undertake an action also influence management decisions [27], studies have found that attitudes influence land management behavior (e.g., [28]) and that on-the-ground biophysical conditions can reciprocally influence attitudes [29].

Though the attitudes of rural landowners may have far-reaching implications for ponds, they are rarely examined outside of the context of human-wildlife conflicts (e.g., [30,31]) or consumption/utilitarianism [32]. Rural decision-making is also influenced by stewardship values [33,34], and it is clear that rural residents value both tangible (i.e., economic) and intangible (i.e., cultural, intrinsic, or aesthetic) benefits provided by wildlife [35]. Pond management is, therefore, likely to be the result of a complex decision-making process where residents weigh both tangible and intangible costs and benefits of management actions. Further exploration of how rural residents' view aquatic wildlife is necessary to understand the potential role of attitudes and values in determining habitat quality in ponds.

\subsection{Objectives}

To understand both the quality of pond habitat and its social drivers in privately owned landscapes, we have several specific objectives. We first worked to determine how ponds are being managed on private lands by examining both historical aerial imagery and high-resolution satellite imagery. We focused particularly on indicators of wildlife habitat quality including: the use of fencing to exclude cattle, the presence and extent of wetland vegetation cover, the rate of pond renovation, pond age, and the proportion of ponds that are temporary. We then worked to understand the social drivers of these habitat quality patterns by integrating remotely sensed data with the results from a landowner survey that measured attitudes toward aquatic wildlife and grassland management. This work, therefore, serves as a case study for the value of linking spatially explicit ecological and social data to inform habitat conservation in working landscapes. Management of ponds on private lands remains a key gap in our knowledge of the capacity of working landscapes to sustain biodiversity. Here, we take a step toward an improved understanding of these abundant but understudied habitats.

\section{Materials and Methods}

\subsection{Study Region}

Our study was conducted in the Grand River Grasslands, a region spanning Ringgold County, Iowa and Harrison County, Missouri (Figure 4). The Grand River Grasslands is located at the northern terminus of the Pond Belt, a pond-dense region that stretches along the eastern edge of the Great Plains from Southeastern Texas to Southwestern Iowa [15]. Ponds are numerous in the region, reaching densities greater than four ponds per $\mathrm{km}^{2}$ [36]. The Grand River Grasslands is dominated by private ownerships, though about $15 \%$ of the area is in reserves [37]. The region is composed of about 515 rural properties that are at least 8 ha (20 acres) in size. Livestock production is a dominant land use for these landowners (70\% graze cattle), but more than half manage diversified properties that also include row-crops [37-39]. The population of the Grand River Grasslands has been experiencing changes common to many rural areas, including aging and retirement of operators and increasing rental acreage [40].

\subsection{Landowner Survey Methods}

We assessed the attitudes of landowners in the region through a mailed survey that was deployed in 2017 [40]. Landowners with $>20$ acres of land were identified using county plat maps purchased from Farm and Home Publishers (Belmond, Iowa, USA). Beginning in February, we contacted landowners five times by mail and once by phone, with two-week intervals between contacts [41]. An online version of the survey through Qualtrics (Qualtrics, Provo, Utah) was made available to landowners to increase the response rate. In the survey, respondents were asked questions related to environmental 
attitudes, land management priorities (e.g., soil erosion, cattle production, income from agriculture, and recreation), and other topics related to grassland management. The sections of the survey were: (1) "Land Information" (acres owned or rented, production activities, and land use), (2) "Making Land Management Decisions" (familiarity with management techniques, and importance of various terrestrial and aquatic wildlife taxa), (3) "Management of Non-Native Grasses" (knowledge and opinions on management of non-native grasses), (4) "Grazing Management" (willingness to adopt management practices), and (5) "About You" (demographic information). To assess attitudes toward aquatic wildlife, landowners were also asked about the importance of having certain taxa on their land ("bullfrogs", "other frogs", "ducks", and "sport fish \{e.g., bass)") and whether they would change their management practices to benefit these organisms (yes/no). Note, while both American bullfrogs (Lithobates catesbeianus) and largemouth bass (Micropterus salmoides) have damaged natural ecosystems (e.g., [42]) when introduced beyond their natural range, they are native to our region and among the most common and well-known inhabitants of ponds in our area [15,43].

(a)

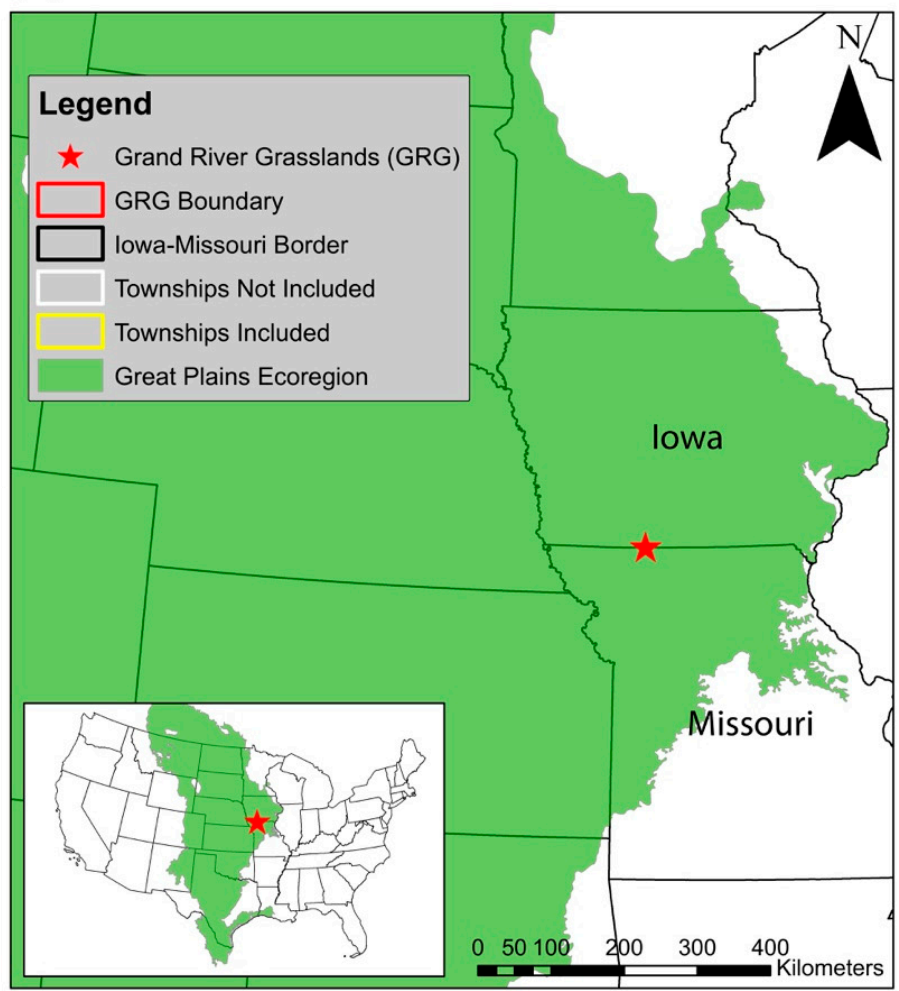

(b)

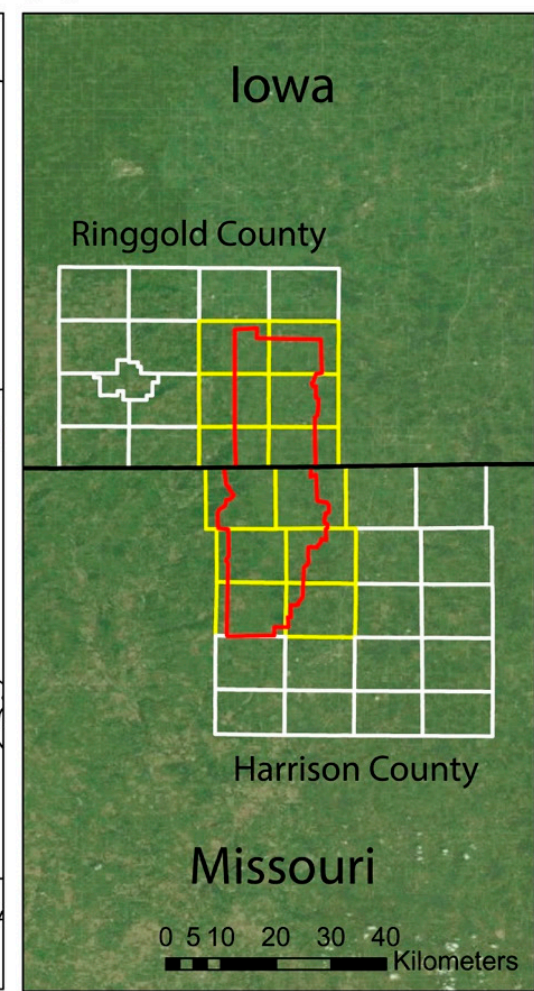

Figure 4. Map depicting (a) the location of the Grand River Grasslands (GRG) within the eastern portion of the Great Plains ecoregion as well as (b) the boundary of the GRG and the townships included in our study.

Questions regarding attitudes were derived from an earlier study completed in the region [38], and were assessed using five-point Likert scales. Language, readability, and formatting were vetted by a pilot-sample of eight Nebraska landowners and by natural resource professionals working in the study region. An interdisciplinary team of wildlife biologists, social scientists, and rangeland scientists developed and approved the survey content.

\subsection{Imagery Acquisition $\mathcal{E}$ Pond Age Estimation}

To understand the links between landowner survey responses and pond management activities, we obtained digital parcel boundaries from the County Assessor's Offices in Harrison and Ringgold counties. We used ESRI ArcMap (v10.5, Environmental Systems Research [ESRI], Redlands, CA, USA) 
to identify and map perimeters of all ponds located on parcels owned by survey respondents using orthorectified aerial imagery of Ringgold County, IA (2013 NAIP, 1 m resolution, USDA) and Harrison county, MO (2016 NAIP imagery, $0.61 \mathrm{~m}$ resolution, USDA).

We used historical aerial imagery to determine pond age and pond renovation rates. This effort was restricted to ponds on parcels in Ringgold County, since historical aerial imagery is not available for Harrison County, MO. Orthorectified imagery of Ringgold County is available from the Iowa Department of Natural Resources (IDNR) Geographic Information Systems (GIS) Database (https: //geodata.iowa.gov/) and the digital archives from the University of Iowa (http://ortho.gis.iastate.edu/) for the following years: 1938, 1947, 1960, 1973, 1983, 1997, 2002, and 2015.

Approximate pond age was determined based on averaging the year of the photograph in which the pond first appeared with the previous imagery year and subtracting this value from 2017. For example, a pond present in 1997 imagery and not present in 1983 imagery was estimated to be approximately 27 years old. We also used historical imagery to assess the renovation status of each pond. Ponds were determined to have been renovated if substantial changes in pond shape, size, or shoreline morphology occurred between two imagery years. Typically, renovation manifested as a small pond with irregular margins in an earlier set of imagery becoming substantially larger and more regular in shape in a subsequent year. For renovated ponds, age was calculated using the imagery year of renovation, rather than year of first appearance, since pond renovation is a destructive process that essentially resets successional state. For example, after accounting for pond renovation, a pond originally constructed between 1960 and 1973 and renovated between 1983 and 1997 was estimated to be about 27 years old. Investigations of pond age and renovation status were conducted in ArcMap.

\subsection{Pond Management Activity}

The digitized boundaries of all ponds were exported to Google Earth where we used high-resolution imagery (imagery date 11 May 2015; approximately $0.15 \mathrm{~m}$ resolution) to determine how landowners manage pond habitat on their lands. We recorded data on a variety of habitat quality and management practice indicators including presence and prevalence of wetland vegetation, cattle access, and fencing presence and effectiveness.

We assessed vegetation cover using three metrics: percent of perimeter with evidence of cattails (Typha spp.) or other emergent vegetation (plants with stems and leaves that extend above the water's surface), percent of the pond surface covered in floating vegetation (such as duckweed [Lemna spp.] or watermeal [Wolffia spp.] which create a green film on the surface of ponds), and percent of pond surface area covered in vegetation of any kind. While each of these genera contains species native to our region, it should be noted that the non-native narrowleaf cattail (Typha angustifolia) and the native-non-native hybrid (Typha $x$ glauca) are also present in our region [44] and could not be differentiated using our methods. While the non-native and hybrid species have been found to outcompete native wetland plants [45], all three Typha species provide habitat for a range of native wildlife species [46-48], which was our focus in this study. Percent cover for the three types of vegetation was visually estimated at six cover classes $(0 \%,>0-5 \%,>5-25 \%,>25-50 \%,>50-75 \%,>75-100 \%)$.

We also used Google Earth imagery to assess whether ponds were on grazed pastures and whether ponds were directly accessible to livestock. Over time, cattle create distinct trails as they traverse pastures or enter and leave a pond, which is visible in Google Earth. Similarly, we determined whether ponds were fenced based on both the geometric patterns fences form around ponds and the contrasting hues of vegetation visible on either side of the fence. We also determined whether fencing was being effectively used to exclude cattle from the pond. If we noted open gates or gaps in the fences where cattle trails crossed the fence boundary into the immediate area of the pond, we considered the fence to be ineffective. We categorized such ponds as being both fenced and cattle accessible.

Finally, we also assessed whether ponds were permanent or temporary by recording whether or not they dried up during severe drought. For this assessment, we used imagery acquired during a severe drought in the summer and early fall of 2012 (after [11]). For our study area, Google Earth 
imagery was available from 5 July 2012, when the severity of the drought began to build, as well as from 28 September 2012, when severity peaked. Ponds were determined to be permanent if any water was still present in the pond basin in the September imagery.

\subsection{Analysis}

\subsubsection{Determining Bias in Sample, Multiple Imputation of Landowner Results}

Prior to analysis, we omitted responses from landowners that completed less than half of the survey $(\mathrm{N}=8)$ and from landowners whose names could not be located in the parcel data provided by the County Assessor's offices $(\mathrm{N}=12)$. Although we had moderate rates of missing data remaining (average 18\%), our dataset passed Little's Test $\left(X^{2}=992.8, \mathrm{DF}=948, p=0.15\right)$, was, therefore, classified as Missing-Completely-At-Random. Likely contributors to missing data were survey formatting for one particular section that was inadvertently skipped by some respondents, although missing data patterns indicate that this skipping was random and not related to other variables or patterns in the dataset. To generate a complete dataset that could be used in analysis, we used multiple imputation in SPSS v.25. The final result was a dataset with 129 complete cases.

\subsubsection{Regression Analyses of Pond Management Activity}

We used general or generalized (in the case of binary response variables) linear mixed-effects models to explore hypotheses related to the links between ten response variables related to pond management and habitat (Table 1). Pond was the fundamental unit of our analyses, with sample size ranging from 188 to 899 , depending on the response variable (Table 1). For each of ten response variables, we generated 25 regression models, each containing one of the candidate predictor variables (Table 2). An intercept-only null model was also generated for each response variable. The identification number of the landowner who owned the pond was included as a random effect in each model since more than one pond could be owned by a single landowner. In total, a set of 26 candidate models were generated for each of the 10 response variables. Prior to analysis, predictor variables were centered and standardized (by subtracting the mean and then dividing by the standard deviation). This allowed us to compare the magnitude of regression coefficients across predictor variables.

Table 1. Key analysis questions and response variables (with sample size of ponds [N]) used in analysis.

\begin{tabular}{ccc}
\hline Dependent Variable & Description & N \\
\hline Pond Age & Age of the pond calculated from dates of historical & 306 \\
imagery & Cover class of cattails along perimeter & 899 \\
\hline Cattails & Cover class of floating vegetation on pond surface & 899 \\
\hline Floating & Cover class of total vegetation on pond surface & 899 \\
\hline Potal Vegetation & Presence or absence of water in pond during height of \\
2012 drought & 899 \\
\hline Renovation & For ponds built before 1990, status of pond as having \\
been renovated or not & 195 \\
\hline Cattle In (grazed) & Presence of cattle in area immediately surrounding the \\
pond on grazed pastures & 421 \\
\hline Cattle Out (grazed and fenced) & Absence of cattle in pond area for fenced ponds on \\
grazed pastures & 188 \\
\hline Fenced & Presence of fence around pond & 899 \\
\hline Fenced (grazed) & Presence of fence around ponds on a grazed pasture & 421 \\
\hline
\end{tabular}


Table 2. Predictor variables from landowner survey used in analysis.

\begin{tabular}{|c|c|}
\hline Predictor Variable & Survey Question or Metric \\
\hline Gender & Gender \\
\hline IncomeTotal & Annual household income before taxes \\
\hline Education & What is the highest level of education you have completed? \\
\hline Age & 2017 minus year born \\
\hline PropIncomeLand & What portion of your household income comes from your land? (\%) \\
\hline AcresOwned & How many acres do you own, rent, or manage in Southern IA/Northern MO? \\
\hline AcresRented & How many acres do you own, rent, or manage in Southern IA/Northern MO? \\
\hline LiveonLand & $\begin{array}{l}\text { Do you currently live on your land? Yes/No. If no, how far do you live from your } \\
\text { land? (miles) }\end{array}$ \\
\hline IncomeAg & $\begin{array}{l}\text { How important to you are each of the following when deciding how to manage } \\
\text { your land? Income from agriculture }\end{array}$ \\
\hline Livestock & $\begin{array}{l}\text { How important to you are each of the following when deciding how to manage } \\
\text { your land? Livestock }\end{array}$ \\
\hline PropertyVal & $\begin{array}{l}\text { How important to you are each of the following when deciding how to manage } \\
\text { your land? Property Values }\end{array}$ \\
\hline EnjoyingLand & $\begin{array}{l}\text { How important to you are each of the following when deciding how to manage } \\
\text { your land? Quietly enjoying my land }\end{array}$ \\
\hline Recreation & $\begin{array}{l}\text { How important to you are each of the following when deciding how to manage } \\
\text { your land? Recreation (hunting/fishing) }\end{array}$ \\
\hline Crops & $\begin{array}{l}\text { How important to you are each of the following when deciding how to manage } \\
\text { your land? Row crops }\end{array}$ \\
\hline Soil & How important to you are each of the following issues? Reducing soil erosion? \\
\hline Biodiversity & How important to you are each of the following issues? Increasing biodiversity? \\
\hline WildlifeHabitat & $\begin{array}{l}\text { How important to you are each of the following issues? Protecting wildlife } \\
\text { habitat? }\end{array}$ \\
\hline Ducks & $\begin{array}{l}\text { How important is it to you to have the following animals/insects on your land? } \\
\text { Ducks (all types) }\end{array}$ \\
\hline Bullfrogs & $\begin{array}{l}\text { How important is it to you to have the following animals/insects on your land? } \\
\text { Bullfrogs }\end{array}$ \\
\hline OtherFrogs & $\begin{array}{l}\text { How important is it to you to have the following animals/insects on your land? } \\
\text { Other frogs }\end{array}$ \\
\hline Sportfish & $\begin{array}{l}\text { How important is it to you to have the following animals/insects on your land? } \\
\text { Sport fish (e.g., bass) }\end{array}$ \\
\hline ManageDucks & Would you change your land management to benefit them? Ducks (all types) \\
\hline ManageBullfrogs & Would you change your land management to benefit them? Bullfrogs \\
\hline ManageOtherFrogs & Would you change your land management to benefit them? Other frogs \\
\hline ManageSportFish & Would you change your land management to benefit them? Sport fish (e.g., bass) \\
\hline Ponds Owned & Number of ponds found on parcel of the pond's owner \\
\hline
\end{tabular}

We utilized an information theoretic approach to differentiate among models in each candidate set. We used Akaike's Information Criterion (AIC; [49]) to identify models with potential explanatory power and gauge the relative strength of these top models. Variables found in models with greater support than the null (intercept-only) model (AIC of model less than that of the null model; [49]) were considered the best supported variables in our candidate set. For these top variables, we generated beta estimates and $85 \%$ confidence intervals to evaluate effect size and precision. Models with $85 \%$ 
confidence intervals that did not overlap zero were considered to be informative and suitable for drawing inference (after [50]). All regression analyses were performed in $\mathrm{R}$ version 3.5.2 [51]. AIC tables were generated with the AICmodavg package [52]. General and generalized linear mixed-effects regressions were performed using the glmer package [53]. Data and code used for analyses are available as Supplementary Material to this article (Code S1, Data S1, and Data S2).

\section{Results}

\subsection{Landowner Survey Respondents}

The survey was completed by 149 individuals with a response rate of $32.7 \%$. We assessed the sample for non-response bias to ensure that it accurately represents the landowners in the Grand River Grasslands, and found little evidence for differences in demographics or management practices [54]. Respondents were $98 \%$ white, and 15\% identified as women. The average age of respondents was 66 years old (range 36-90). Nearly all respondents were high school graduates, with over $60 \%$ having post-secondary education. The reported size of parcels ranged from 16 to 3000 acres (mean 851.2), with an average 313.8 acres in grassland (mean 202.6 acres grazed), 145.8 acres in corn or soy, and 47.0 acres in woodland. On average, respondents derived $41 \%$ of their income from their land, though this proportion was highly variable $(S D=34 \%)$. Of all respondents, $32 \%$ identified themselves as absentee landowners, and 17\% lived at least 50 miles from their land [40]. Soil erosion was a top-priority for respondents, with $91 \%$ rating it as a moderately-extremely important consideration.

A majority of landowners viewed aquatic wildlife positively: $82 \%$ of respondents ranked sport fish as moderately to extremely important to have on their properties, $67 \%$ for bullfrogs, $61 \%$ for other frogs, and $60 \%$ for ducks. In addition, over half were willing to change their land management to enhance habitat for sport fish (57\%), 47\% willing for ducks, $42 \%$ for bullfrogs, and 35\% for other frogs.

\subsection{Pond Habitat and Management Characteristics}

On average, pond surface area was 0.71 acres $(S D=1.03)$ with a range of 0.02 to 11.05 acres. Historical imagery available for ponds in Ringgold County allowed us to estimate the approximate age and renovation status of 306 ponds on 50 parcels owned by survey respondents. Mean pond age was 35.1 years old $(S D=20.6$, median $=27.0)$. Most ponds were less than 50 years old (Figure $5 a)$. All ponds were assessed for vegetation $(\mathrm{N}=899)$. Vegetation cover was low or non-existent for many ponds, with only $232(25.8 \%)$ having cattails or other emergent vegetation along their perimeters (Figure $5 b$ ). Even fewer ponds exhibited cover of floating vegetation on their surface (Figure $5 \mathrm{c}$ ). While a total of 655 ponds $(72.3 \%)$ had at least trace amounts of vegetation cover, 703 ponds had less than $5 \%$ total vegetation cover $(78.2 \%$; Figure $5 \mathrm{~d})$.

We found evidence that $28.7 \%$ of all ponds evaluated had been renovated (88 of 306 ) and $37.9 \%$ of ponds older than 40 years had been renovated (74 of 195; Figure 5e). Of the ponds that were renovated, the average age at renovation was 27.2 years old $(S D=20.0$, median $=30.0)$. Without renovation, ponds on our study landscape would have been 41.8 years old, on average $(S D=20.5$, median $=48.0$ ). Our drought year comparisons indicated that only 15.7\% (141 of 899) of ponds on our study parcels were temporary and dried during the 2012 drought (Figure $5 \mathrm{f}$ ).

Fences were absent from most ponds, with only $25.8 \%$ of all ponds being fully fenced (232 of 899; Figure $5 \mathrm{~g})$. About half of the ponds in our study were located on grazed cattle pastures $(46.8 \%$, $\mathrm{N}=421$ ), with the rest embedded in other uses including fallow fields, crop fields, or residential parcels. Of the ponds on grazed pastures, 302 (71.7\%) were directly accessible to cattle (Figure 5h). Fencing was prevalent among ponds on grazed pastures, but its effectiveness in preventing cattle from having direct access to ponds was inconsistent. Indeed, of the 188 ponds located on grazed pastures that were completely fenced (44.7\%), 69 (36.7\%) were accessible to cattle (Figure 5i). In nearly all of these, it was clear that cattle were accessing ponds through an open gate rather than through a hole or gap in the fence. 
(a)

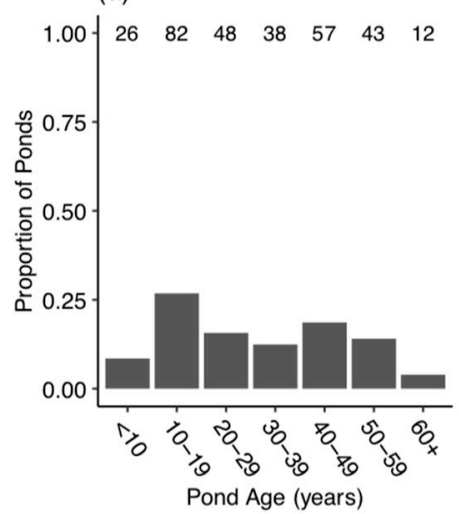

(d)

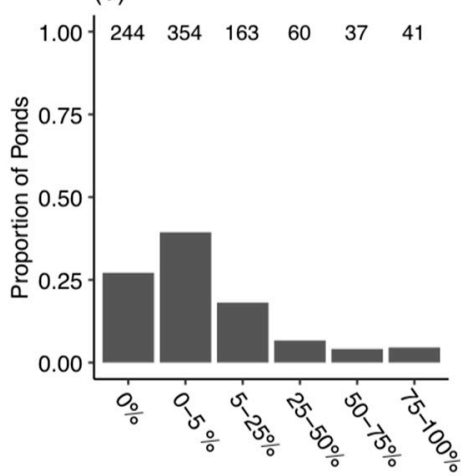

Total Vegetation Cover

(g)

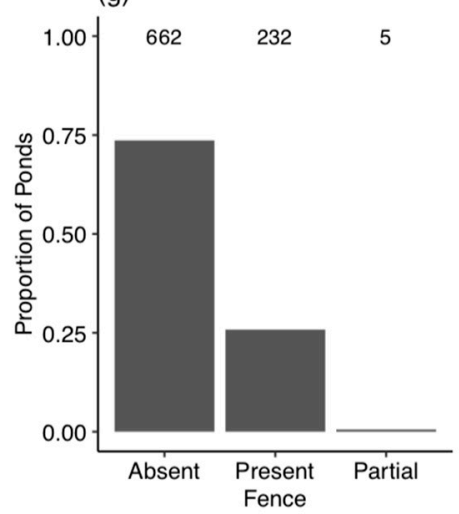

(b)

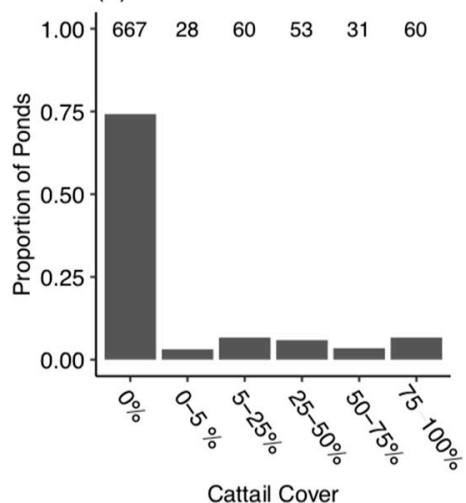

(e)

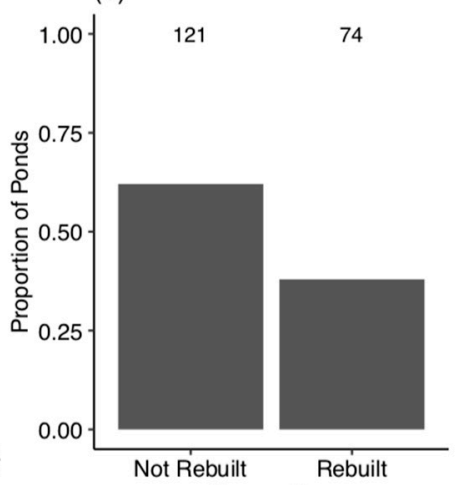

Renovation

(h)

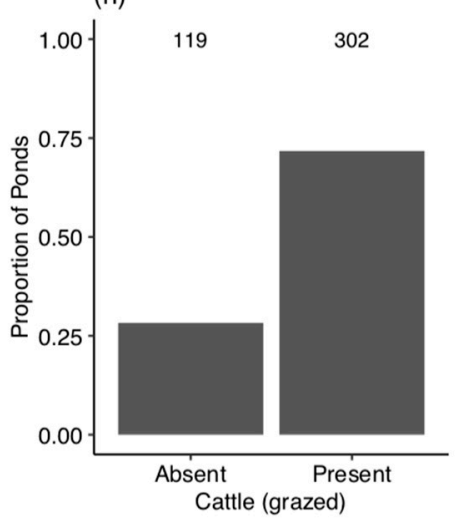

(c)

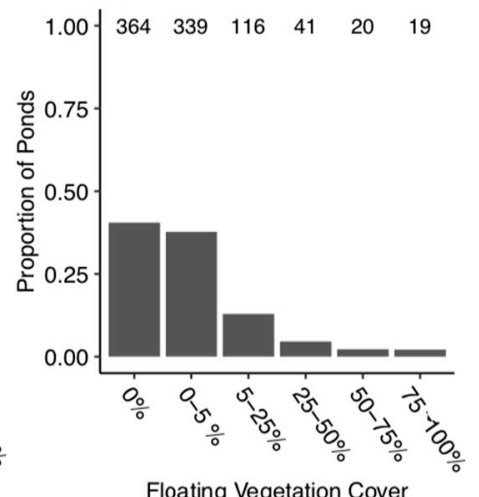

(f)

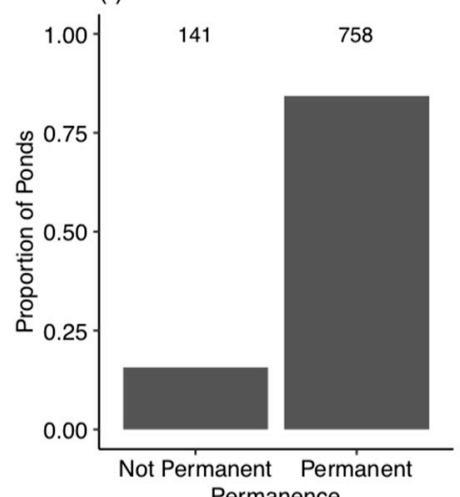

Permanence

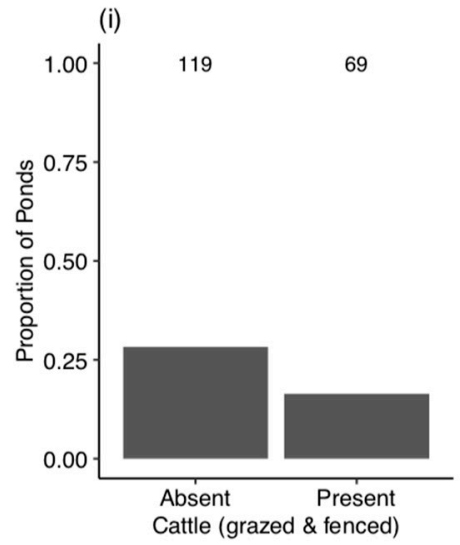

Figure 5. Bar graphs depicting frequency distributions of the estimated ages, vegetation cover, renovation status of ponds older than 40 years, cattle and fence presence, and permanence of farm ponds found in Ringgold County, Iowa, based on historical aerial imagery. The number of ponds in a category is displayed above level.

\subsection{Mixed Effects Regression Models}

Based on our model selection criteria, several variables from the landowner survey were found to influence pond management indicators (Table 3). Although model selection uncertainty is apparent for some response variables (models rarely achieved $>90 \%$ AIC weight), these results provide a basis for future exploration of the links between the characteristics and attitudes of landowners and the ponds they manage. For all response variables except floating vegetation cover, at least one model containing a predictor variable ranked better than the null model of the set. 
Table 3. Model selection results from general/generalized linear regression for nine response variables (see Table 1 for descriptions). Only models ranking better than the null model (based on $\Delta \mathrm{AIC}$ ) are shown. $\triangle \mathrm{AIC}=$ the difference between the top model and a competing model; $w_{i}=$ Akaike weight, interpreted as the probability that the given model is the best-approximating model of the candidate set; $K=$ the number of estimable parameters in the model, including the intercept; Evidence ratio = an indication of the relative support for a given model compared with the null model, $w_{i} / w_{N u l l}$.

\begin{tabular}{|c|c|c|c|c|c|c|c|}
\hline $\begin{array}{l}\text { Response } \\
\text { Variable }\end{array}$ & Predictor Variable & $K$ & AIC & $\Delta \mathrm{AIC}$ & $w_{i}$ & Log-Likelihood & $\begin{array}{c}\text { Evidence } \\
\text { Ratio }\end{array}$ \\
\hline \multirow[t]{3}{*}{ Pond Age } & IncomeAg & 4 & 2724.36 & 0.00 & 0.09 & -1358.18 & 1.50 \\
\hline & Crops & 4 & 2724.87 & 0.52 & 0.07 & -1358.44 & 1.17 \\
\hline & Null & 3 & 2724.93 & 0.58 & 0.06 & -1359.47 & - \\
\hline \multirow[t]{8}{*}{ Cattails } & Crops & 4 & 3317.19 & 0.00 & 0.77 & -1654.60 & 77.00 \\
\hline & Age & 4 & 3322.74 & 5.55 & 0.05 & -1657.37 & 5.00 \\
\hline & IncomeAg & 4 & 3323.18 & 5.99 & 0.04 & -1657.59 & 4.00 \\
\hline & IncomeTotal & 4 & 3324.14 & 6.95 & 0.02 & -1658.07 & 2.00 \\
\hline & AcresRented & 4 & 3325.25 & 8.05 & 0.01 & -1658.62 & 1.00 \\
\hline & WildlifeHabitat & 4 & 3325.81 & 8.62 & 0.01 & -1658.91 & 1.00 \\
\hline & Livestock & 4 & 3326.20 & 9.01 & 0.01 & -1659.10 & 1.00 \\
\hline & Null & 3 & 3326.31 & 9.12 & 0.01 & -1660.16 & - \\
\hline \multirow[t]{6}{*}{ TotalVeg } & IncomeTotal & 4 & 3025.68 & 0.00 & 0.15 & -1508.84 & 3.00 \\
\hline & IncomeAg & 4 & 3026.24 & 0.56 & 0.11 & -1509.12 & 2.20 \\
\hline & Crops & 4 & 3026.78 & 1.10 & 0.09 & -1509.39 & 1.80 \\
\hline & ManageSportFish & 4 & 3027.11 & 1.43 & 0.07 & -1509.55 & 1.40 \\
\hline & Education & 4 & 3027.37 & 1.69 & 0.06 & -1509.68 & 1.20 \\
\hline & Null & 3 & 3028.04 & 2.37 & 0.05 & -1511.02 & - \\
\hline Floating & Null & 3 & 2756.93 & 0.00 & 0.07 & -1375.47 & - \\
\hline \multirow[t]{4}{*}{ Renovated } & ManageBullfrogs & 3 & 260.43 & 0.00 & 0.14 & -127.22 & 2.33 \\
\hline & Gender & 3 & 261.17 & 0.74 & 0.10 & -127.59 & 1.67 \\
\hline & Crops & 3 & 262.20 & 1.76 & 0.06 & -128.10 & 1.00 \\
\hline & Null & 2 & 262.29 & 1.85 & 0.06 & -129.14 & - \\
\hline \multirow[t]{4}{*}{$\begin{array}{c}\text { Cattle In } \\
\text { (grazed ponds) }\end{array}$} & OtherFrogs & 3 & 474.86 & 0.00 & 0.10 & -234.43 & 1.67 \\
\hline & Bullfrogs & 3 & 475.33 & 0.47 & 0.08 & -234.66 & 1.33 \\
\hline & Age & 3 & 475.55 & 0.69 & 0.07 & -234.78 & 1.17 \\
\hline & Null & 2 & 475.98 & 1.12 & 0.06 & -235.99 & - \\
\hline \multirow{6}{*}{$\begin{array}{c}\text { Cattle Out } \\
\text { (grazed \& } \\
\text { fenced ponds) }\end{array}$} & Livestock & 3 & 239.39 & 0.00 & 0.09 & -116.69 & 1.50 \\
\hline & Bullfrogs & 3 & 239.76 & 0.38 & 0.08 & -116.88 & 1.33 \\
\hline & OtherFrogs & 3 & 239.84 & 0.45 & 0.07 & -116.92 & 1.17 \\
\hline & Age & 3 & 240.12 & 0.73 & 0.06 & -117.06 & 1.00 \\
\hline & LiveonLand & 3 & 240.12 & 0.73 & 0.06 & -117.06 & 1.00 \\
\hline & Null & 2 & 240.28 & 0.89 & 0.06 & -118.14 & - \\
\hline \multirow[t]{9}{*}{ Fenced } & Livestock & 3 & 916.15 & 0.00 & 1.00 & -455.08 & - \\
\hline & WildlifeHabitat & 3 & 943.29 & 27.14 & 0.00 & -468.65 & - \\
\hline & LiveonLand & 3 & 948.94 & 32.79 & 0.00 & -471.47 & - \\
\hline & Ducks & 3 & 949.74 & 33.59 & 0.00 & -471.87 & - \\
\hline & Recreation & 3 & 950.01 & 33.86 & 0.00 & -472.01 & - \\
\hline & Crops & 3 & 951.04 & 34.89 & 0.00 & -472.52 & - \\
\hline & IncomeAg & 3 & 951.23 & 35.08 & 0.00 & -472.62 & - \\
\hline & PropIncomeLand & 3 & 951.48 & 35.33 & 0.00 & -472.74 & - \\
\hline & Null & 2 & 952.67 & 36.52 & 0.00 & -474.34 & - \\
\hline \multirow[t]{4}{*}{ Fenced (grazed) } & ManageSportFish & 3 & 563.45 & 0.00 & 0.09 & -278.72 & 1.50 \\
\hline & Crops & 3 & 563.66 & 0.21 & 0.08 & -278.83 & 1.33 \\
\hline & SportFish & 3 & 564.00 & 0.55 & 0.07 & -279.00 & 1.17 \\
\hline & Null & 2 & 564.31 & 0.87 & 0.06 & -280.16 & - \\
\hline \multirow[t]{3}{*}{ Permanent } & Ponds Owned & 3 & 773.96 & 0.00 & 0.34 & -383.98 & 6.80 \\
\hline & Education & 3 & 777.12 & 3.17 & 0.07 & -385.56 & 1.40 \\
\hline & Null & 2 & 777.90 & 3.95 & 0.05 & -386.95 & - \\
\hline
\end{tabular}


Pond age was inversely correlated to both importance of income from agriculture and row crops (Figure 6a). Ponds owned by those who rated these items more highly tended to be newer. Cattail prevalence was best predicted by importance of row crops, which carried a substantial portion of the AIC weight in the model set $\left(w_{i}=0.77\right)$. Cattail cover tended to be lower in ponds of respondents who rated importance of income from row crops highly (Figure $6 \mathrm{~b}$ ). Other variables carried substantially less weight $\left(w_{i}<0.1\right)$. Total vegetation cover of ponds was negatively related to total income, importance of income from agriculture, importance of row crops, and respondent's education level; and positively related to willingness to change management for sport fish (Figure $6 \mathrm{c}$ ). For floating vegetation cover, there were no variables with more support than the null model.

(a) Pond Age

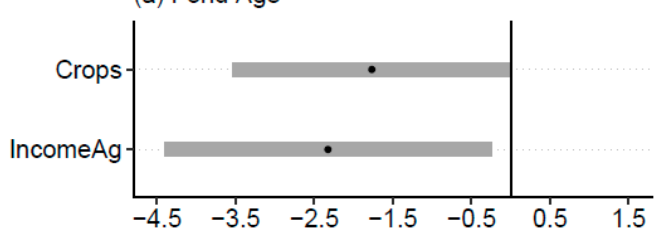

(c) TotalVeg

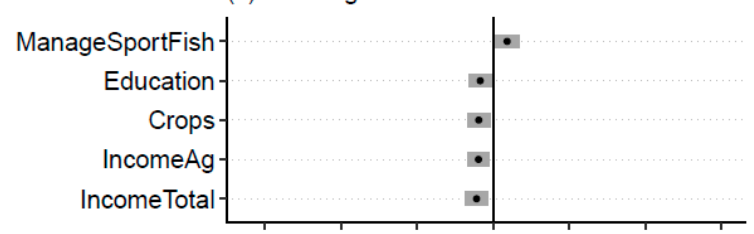

(e) Cattle In (grazed ponds)

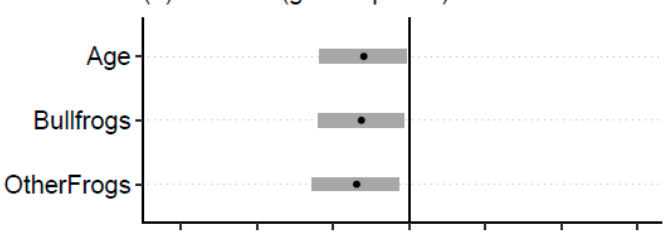

(g) Fenced

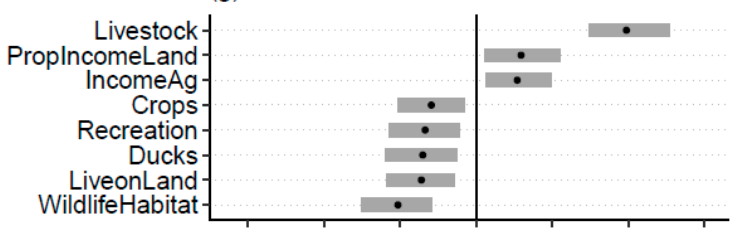

(i) Permanent

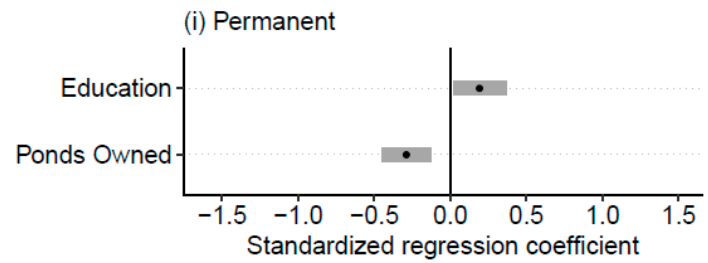

(b) Cattails

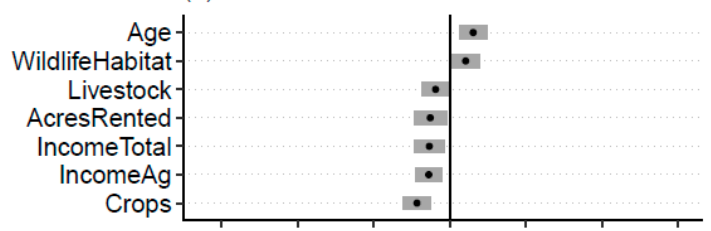

(d) Renovated
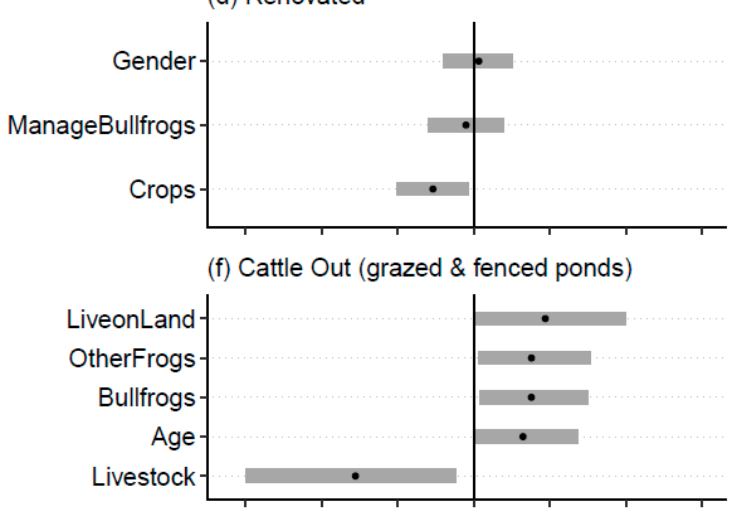

(h) Fenced (grazed ponds)

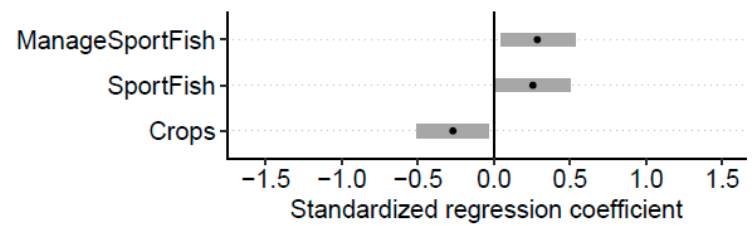

Figure 6. Estimated effect size (standardized regression coefficient from mixed-effects regression; black dot) and $85 \%$ confidence intervals (gray bars) for eight response variables related to management and habitat quality of ponds in Southern Iowa. For each response variable, only predictor variables with greater support than the null model are shown (based on Akaike's Information Criterion [AIC]; see Table 2). Note, for Pond Age, tick marks are spaced at one-unit intervals.

The likelihood that a pond built prior to 1990 had been renovated was negatively related to importance of income from row crops. It was also negatively related to landowner's willingness to change their management for bullfrogs and positively to gender (ponds owned by female respondents tended to not be renovated), though the confidence intervals for these two variables overlapped zero (Figure 6d), indicating these two to be uninformative parameters (see [50]). 
Ponds on grazed pastures were less likely to be accessible to cattle if the landowner regarded having other frogs or bullfrogs on their land as more important (Figure 6e). Ponds owned by older respondents were also less likely to be accessible to cattle. For ponds on grazed pastures that were fenced, cattle were more likely to be excluded from the pond (i.e., the fence was properly functioning) if a respondent regarded having bullfrogs or other frogs on their land as important, was older, or lived on their land. Fences around ponds owned by those who rated livestock as more important were less likely to be functioning properly (Figure 6f).

Across all ponds, the importance of livestock was the best predictor of whether or not a pond was fenced $\left(w_{i}=1.00\right)$, with ponds more likely to be fenced if owned by those who regarded livestock as important (Figure 6g). On grazed parcels, ponds were fenced if the respondent was willing to change their land management to benefit sport fish and if sport fish were important. Ponds were less likely to be fenced if row crops were rated highly (Figure $6 \mathrm{~h}$ ). The likelihood that a pond was permanent was best predicted by the number of ponds owned $\left(w_{i}=0.34\right)$, though education level received some support (0.07). A pond was more likely to be permanent if it was owned by a landowner with more ponds (Figure 6i).

\section{Discussion}

Landscape ecologists have a long record of using remote sensing to gain information on spatial arrangement and potential quality of wildlife habitat (e.g., [55,56]). However, the underlying attitudes, beliefs, and values of landowners, and their links with observed ecological and land management patterns, can be more difficult to assess.

Broadly, our results show that many landowners value wildlife, including amphibians, and that some ponds in the region are already managed in ways that likely benefit aquatic organisms. It is notable that most respondents viewed as moderately to extremely important not only ducks and fish, which are commonly harvested recreationally, but also frogs, which have limited economic or recreation value (but see [57]). We recommend that future development of effective messaging and communication to landowners take into account our finding that many residents in the U.S. Great Plains hold positive views toward these organisms. They may already be receptive to adopting conservation measures that benefit amphibians and other wildlife.

Though our results reveal some important avenues for future research, they also highlight the challenges of linking these data in a single analysis. For most response variables, model AIC weight and the magnitude of effect sizes for supported predictor variables (based on standardized regression coefficients) tended to be small and confidence intervals were sometimes wide. To avoid drawing inference from uninformative parameters, we focus our interpretation on variables for which confidence intervals did not overlap zero, but the uncertainty surrounding these estimates hints at a larger challenge of capturing the complexities of land management behavior in a regression modeling process [58]. For example, we based our management and habitat assessments on high-resolution satellite imagery, but the tools we used to assess habitat quality are likely different from those used by landowners to assess their properties [59]. This could obscure the links between our assessments of habitat quality and the social drivers of management actions. Structured pond-side interviews with landowners, like those conducted by Greenland-Smith, Brazner and Sherren [23] in Nova Scotia, could be highly beneficial, especially when coupled to an on-the-ground ecological assessment of a pond. These methods could delve more deeply into the patterns we have noted through remote sensing. They would also allow exploration of additional factors that may affect wetland quality (such as pollution from pesticide or fertilizer runoff) that we could not assess through the methods employed here. We encourage future research to test the relationships between actual and perceived habitat quality and believe the results from the present study provide the groundwork for these efforts.

We found evidence that positive attitudes toward aquatic wildlife sometimes correlated with beneficial management practices. For example, fences were more likely to be effectively preventing cattle access to ponds, and thereby protecting water quality, if the respondent rated the importance of 
frogs more highly. At the same time, we noted that certain economic attitudes may lead to prioritization of agricultural goals over habitat conservation.

Most of the 899 ponds in our sample were found to be optimized for agricultural function, not wildlife conservation. Specifically, most ponds were fairly new (most were $<40$ years old), had limited cover of wetland vegetation (especially cattails and emergent vegetation), and were permanent, even in severe drought. The bias toward newer ponds indicated that most are likely in early successional stages and of limited conservation value for many organisms. For example, without wetland vegetation, productivity of ponds is limited for many amphibian species that utilize wetland vegetation as substrate for oviposition, foraging habitat, and refuge from predators [60]. Similarly, permanent ponds are suboptimal habitat for many aquatic organisms that require periodic cycles of wetland drying to eliminate predators like fish [61]. As a result, the biological community of most ponds is likely dominated by species preferring permanent wetlands (e.g., American bullfrogs and other Lithobates spp.). Species of conservation concern that require temporary habitats or late-successional conditions (e.g., Hyla chrysoscelis or Acris blanchardi) [15] may be absent from the majority of ponds as they are currently managed.

The trends we observed in habitat and management characteristics of ponds related to several of our survey items. Ponds tended to be newer if they were owned by respondents who viewed income from agriculture and row crops as important. Cattail and total vegetation cover were also lower in ponds owned by these respondents. These relationships suggest that landowners with economic and agricultural priorities are less likely to have older ponds late successional habitat. On the other hand, age of respondent was associated with greater cattail cover. Previous studies in other landscapes have linked increasing landowner age to decreasing investment in land management $[62,63]$. This may be true for ponds as well, with increased levels of cattail coverage indicating lower management efforts. If the availability of any late-successional habitat in ponds is indeed due to neglect, rather than intentional conservation, it is vulnerable to any changes in the socio-economic context.

As was the case with other indicators of habitat quality, our assessment of pond permanence indicated that certain habitat types are scarce. Temporary ponds made up just $15.7 \%$ of all ponds we assessed. This is not surprising given that agricultural function is optimized when ponds are deep and drought resistant. Considering the unique ecological role temporary wetlands play in supporting specialist organisms (e.g., $[64,65])$, this finding is worrisome for aquatic wildlife conservation. At the same time, the best predictor of non-permanence was the number of ponds owned by the respondent. Landowners with many ponds may be able to accommodate decreased agricultural function in a few since other suitable ones are available. This correlates with findings from central Texas where low-functioning ponds proliferated on the landscape as more ponds were built [20]. As long as appropriate sites are available elsewhere to construct new ponds, landowners may be willing to allow ponds to age with little interference. Our results suggest that these landowners may represent a group that could be targeted for outreach. Given that they appear to be able to tolerate a decrease in the core function of some of their ponds, they may also be willing to accommodate improvements focused on conserving wildlife habitat in these sites.

Unlike other indicators, rates of pond renovation were relatively favorable for wildlife. Since agricultural function is expected to decline substantially as ponds age [8], we expected renovation to be widespread. In fact, less than $38 \%$ of ponds $\geq 40$ years old had been renovated, a similar rate to that observed in Texas [20]. More late-successional ponds may be available than anticipated. Ponds were less likely to be renovated if row crops were viewed as more important. Row crop farming is less directly reliant on farm pond function than cattle production, and renovation may be less of a priority for these landowners for this reason. However, we also found that both cattails and total vegetation were negatively correlated to row crop importance. Future study of how row crop farmers, cattle producers, and other landowners differ in their perception and management goals for their ponds, specifically with regard to renovation, could provide valuable insights into conservation opportunities. Farm ponds in the U.S. lack federal wetland protections and are, therefore, all at risk of renovation. It 
will be critical to identify economic and social mechanisms underlying this behavior if pond habitats are to be conserved.

This study also explored the extent to which fencing is effectively implemented for farm ponds in the Great Plains. Although this practice is widely recommended to protect water quality and wildlife habitat and can be implemented through cost-share programs with the Natural Resources Conservation Service (NRCS) [18], fencing was not very common for ponds in our sample. Only $25.8 \%$ of all ponds were fully fenced. Ponds tended to be fenced if livestock or income from agriculture were rated highly but tended not to be fenced if wildlife habitat, ducks, recreation, and row crops were regarded as more important and if the respondent lived on their land. This pattern is likely due to fences being unnecessary on lands not devoted to cattle production. For ponds located on grazed lands, we found that many fences were not functioning properly, and the majority of these ponds were directly accessible to cattle. Cattle were less likely to be excluded from fenced ponds if livestock were viewed as important or if landowners did not live on their land, but more likely to be excluded from ponds owned by older respondents or those rating bullfrogs or other frogs as important. This provides an indication that landowners with positive views toward frogs may have a greater interest in or knowledge of the wildlife habitat value of ponds, as reflected by their apparent efforts to ensure fences are functioning. Given this potential link, these landowners could be candidates for future outreach and partnership for habitat conservation. Government organizations that subsidize fence installation including the NRCS may need to conduct follow-up assessments to ensure that they are being used properly. Ensuring proper function and widespread installation of fences is a simple yet effective way for landowners to preserve the quality of pond habitats [66].

\section{Conclusions}

Our study provides evidence that the current management practices of farm ponds in Great Plains may severely limit the value of many for wildlife conservation. Most ponds are managed for agricultural functions. However, our work also provides reason to be somewhat optimistic about the future of farm pond habitat conservation and indicates several directions for outreach, landowner education, and partnership. Landowners who value aquatic wildlife and are already managing their ponds in ways that likely benefit wildlife may constitute a small, core set of future partners for conservation efforts focused on improved management of ponds in the region. That more than $60 \%$ of landowners view aquatic wildlife positively suggests that providing support (e.g., incentives, equipment sharing, and information products) for management practices that benefit aquatic wildlife will be tractable with many in this region.

In addition, our results suggest that outreach efforts targeted at older or retired landowners who do not rely on their properties for income could be effective. At the same time, financial incentives like those provided by the Conservation Reserve Program may be necessary to encourage income-focused producers who own many ponds to create and conserve pond habitats. One option may be to compensate landowners who let at least some of their ponds proceed through succession [15].

These programs would rely on voluntary enrollment, since ponds are not considered wetlands under the terms of the Clean Water Act (1972) and so are not subject to the protections and regulations afforded to their natural counterparts. Natural resource agencies at both the federal [66] and state level [67] are interested in promoting wildlife habitat in ponds, but formal programs for ponds have yet to be developed. Investigating the feasibility of programs that incentivize the effective exclusion of cattle, the growth of wetland vegetation, and the preservation of older and temporary ponds should be a priority for policymakers and natural resource agencies. This study provides a starting point for catalyzing such efforts, but future work is needed to identify logistical and agronomic barriers to the implementation of such programs.

Although here we have worked to consider the links between the attitudes and values of landowners and the habitats they manage, other approaches could supplement this effort. We noted differences in pond management practices among landowners to whom crops or cattle were important. 
Formalizing these differences using a typology based on farming system (e.g., [68]) may provide a useful way to group landowners with similar priorities and concerns and use these groupings to identify additional opportunities for advancing wildlife conservation on private lands.

These insights were gained by integrating remotely sensed information on landowner behavior, specifically pond management related to wildlife habitat, with the underlying attitudes held by the landowners. This approach relied on having high-resolution and spatially congruent data on both social and ecological parameters. Though this collection of data may be difficult to acquire, we believe this study provides an example of the value of doing so. We encourage future efforts that work to extend this approach to address land management concerns in the context of not only farm ponds but also other ecosystems in working landscapes where an unseen mosaic of social drivers underlie management behavior.

Supplementary Materials: The following are available online at http://www.mdpi.com/2073-445X/8/9/127/s1, Code S1: Descriptive statistics and mixed effects regression, Data S1: Pond habitat and landowner response data, Data S2: Regression model coefficients and confidence intervals.

Author Contributions: Conceptualization, T.M.S. and J.J.C.; methodology, T.M.S., J.J.C., J.R.M. (Jenna R. Mattes); formal analysis, T.M.S. and J.J.C.; validation, T.M.S., J.J.C. and J.R.M. (Jenna R. Mattes); investigation, T.M.S., J.J.C., J.R.M. (Jenna R. Mattes); resources, J.R.M. (James R. Miller).; data curation, T.M.S., J.J.C., J.R.M. (Jenna R. Mattes).; writing - original draft preparation, T.M.S., J.J.C., and J.R.M. (Jenna R. Mattes); writing—review and editing, J.R.M. (Jenna R. Mattes), and J.R.M. (James R. Miller).; visualization, T.M.S.; supervision, J.R.M. (James R. Miller); project administration, J.R.M. (James R. Miller); funding acquisition, J.R.M. (Jenna R. Mattes) and J.R.M. (James R. Miller).

Funding: This research was supported by an ACES Undergraduate Research Scholarship Program granted to J. Mattes by the College of Agricultural, Consumer, and Environmental Sciences at the University of Illinois at Urbana-Champaign. This work was partially supported by USDA Sustainable Agriculture Research and Education, North-Central Region [GSP15-038].

Acknowledgments: We are grateful to Scott Maresh Nelson for feedback during early stages of project development. We also thank the landowners who shared their views and opinions on the survey. We thank Lois Wright Morton and Carena van Riper for assistance with survey design and administration. We are indebted to Adam Gottemoeller and Shannon Rusk for their insights into farm pond construction and maintenance in Iowa and Missouri. We are also grateful to Adam Gottemoeller for providing the photograph for Figure 3b. All other photographs were provided by TS.

Conflicts of Interest: The authors declare no conflict of interest. The funders had no role in the design of the study; in the collection, analyses, or interpretation of data; in the writing of the manuscript, or in the decision to publish the results.

\section{References}

1. Tscharntke, T.; Klein, A.M.; Kruess, A.; Steffan-Dewenter, I.; Thies, C. Landscape perspectives on agricultural intensification and biodiversity-ecosystem service management. Ecol. Lett. 2005, 8, 857-874. [CrossRef]

2. Mora, C.; Sale, P.F. Ongoing global biodiversity loss and the need to move beyond protected areas: A review of the technical and practical shortcomings of protected areas on land and sea. Mar. Ecol. Prog. Ser. 2011, 434, 251-266. [CrossRef]

3. Jenkins, C.N.; Van Houtan, K.S.; Pimm, S.L.; Sexton, J.O. US protected lands mismatch biodiversity priorities. Proc. Natl. Acad. Sci. USA 2015, 112, 5081-5086. [CrossRef] [PubMed]

4. Bigelow, D.P.; Borchers, A. Major Uses of Land in the United States. 2012. Available online: https: //www.ers.usda.gov/publications/pub-details/?pubid=84879 (accessed on 22 August 2019).

5. Cannavò, P.F. The Working Landscape: Founding, Preservation and the Politics of Place; MIT Press: Cambridge, Massachusetts, USA, 2007; p. 425.

6. Maresh Nelson, S.B.; Coon, J.J.; Duchardt, C.J.; Miller, J.R.; Debinski, D.M.; Schacht, W.H. Contrasting impacts of invasive plants and human-altered landscape context on nest survival and brood parasitism of a grassland bird. Landsc. Ecol. 2018, 33, 1799-1813. [CrossRef]

7. Shew, J.J.; Nielsen, C.K.; Sparling, D.W. Finer-scale habitat predicts nest survival in grassland birds more than management and landscape: A multi-scale perspective. J. Appl. Ecol. 2019, 56, 929-945. [CrossRef]

8. Chumchal, M.M.; Drenner, R.W. An environmental problem hidden in plain sight? Small Human-made ponds, emergent insects, and mercury contamination of biota in the Great Plains. Environ. Toxicol. Chem. 2015, 34, 1197-1205. [CrossRef] [PubMed] 
9. Compton, L.V. Farm and ranch ponds. J. Wildl. Manag. 1952, 16, 238-242. [CrossRef]

10. Gallant, A.L.; Sadinski, W.; Roth, M.F.; Rewa, C.A. Changes in historical Iowa land cover as context for assessing the environmental benefits of current and future conservation efforts on agricultural lands. J. Soil Water Conserv. 2011, 66, 67A-77A. [CrossRef]

11. Chumchal, M.M.; Drenner, R.W.; Adams, K.J. Abundance and size distribution of permanent and temporary farm ponds in the southeastern Great Plains. Inland Waters 2016, 6, 258-264. [CrossRef]

12. Renwick, W.H.; Sleezer, R.O.; Buddemeier, R.W.; Smith, S.V.Small artificial ponds in the United States: Impacts on sedimentation and carbon budget. In Proceedings of the Eighth Federal Interagency Sedimentation Conference, Reno, NV, USA, 2-6 April 2006; pp. 73-744.

13. Knutson, M.G.; Richardson, W.B.; Reineke, D.M.; Gray, B.R.; Parmelee, J.R.; Weick, S.E. Agricultural ponds support amphibian populations. Ecol. Appl. 2004, 14, 669-684. [CrossRef]

14. Shulse, C.D.; Semlitsch, R.D.; Trauth, K.M.; Williams, A.D. Influences of design and landscape placement parameters on amphibian abundance in constructed wetlands. Wetlands 2010, 30, 915-928. [CrossRef]

15. Swartz, T.M.; Miller, J.R. Managing farm ponds as breeding sites for amphibians: Key trade-offs in agricultural function and habitat conservation. Ecol. Appl. 2019. [CrossRef] [PubMed]

16. Trimble, S.W.; Mendel, A.C. The cow as a geomorphic agent-A critical review. Geomorphology 1995, 13, 233-253. [CrossRef]

17. Trimble, S.W. Erosional effects of cattle on streambanks in Tennessee, USA. Earth Surf. Process. Landf. 1994, 19, 451-464. [CrossRef]

18. Giuliano, W.M. Should I fence the streams, ponds and wetlands in my pastures? Fencing pasture streams, ponds and wetlands can improve fish and wildlife habitat and benefit agricultural landowners. Rangelands 2006, 28, 29-31. [CrossRef]

19. Reinartz, J.A.; Warne, E.L. Development of vegetation in small created wetlands in southeastern Wisconsin. Wetlands 1993, 13, 153-164. [CrossRef]

20. Berg, M.D.; Popescu, S.C.; Wilcox, B.P.; Angerer, J.P.; Rhodes, E.C.; McAlister, J.; Fox, W.E. Small farm ponds: Overlooked features with important impacts on watershed sediment transport. J. Am. Water Resour. Assoc. 2016, 52, 67-76. [CrossRef]

21. Schonrock, A.E. An Internet Survey of Private Pond Owners and Managers in Texas; Texas A\&M: College Station, TX, USA, 2005.

22. Goldberg, C.S.; Waits, L.P. Using habitat models to determine conservation priorities for pond-breeding amphibians in a privately-owned landscape of northern Idaho, USA. Biol. Conserv. 2009, 142, 1096-1104. [CrossRef]

23. Greenland-Smith, S.; Brazner, J.; Sherren, K. Farmer perceptions of wetlands and waterbodies: Using social metrics as an alternative to ecosystem service valuation. Ecol. Econ. 2016, 126, 58-69. [CrossRef]

24. Bennett, N.J.; Roth, R.; Klain, S.C.; Chan, K.; Christie, P.; Clark, D.A.; Cullman, G.; Curran, D.; Durbin, T.J.; Epstein, G. Conservation social science: Understanding and integrating human dimensions to improve conservation. Biol. Conserv. 2017, 205, 93-108. [CrossRef]

25. Teel, T.L.; Manfredo, M.J.; Jensen, F.S.; Buijs, A.E.; Fischer, A.; Riepe, C.; Arlinghaus, R.; Jacobs, M.H. Understanding the cognitive basis for human-wildlife relationships as a key to successful protected-area management. Int. J. Sociol. 2010, 40, 104-123. [CrossRef]

26. Heberlein, T.A. Navigating environmental attitudes. Conserv. Biol. 2012, 26, 583-585. [CrossRef] [PubMed]

27. Ajzen, I. The theory of planned behavior. Organ. Behav. Hum. Decis. Process. 1991, 50, 179-211. [CrossRef]

28. Ferranto, S.; Huntsinger, L.; Getz, C.; Lahiff, M.; Stewart, W.; Nakamura, G.; Kelly, M. Management without borders? A survey of landowner practices and attitudes toward cross-boundary cooperation. Soc. Nat. Resour. 2013, 26, 1082-1100. [CrossRef]

29. Stedman, R.C. Is it really just a social construction? The contribution of the physical environment to sense of place. Soc. Nat. Resour. 2003, 16, 671-685. [CrossRef]

30. Treves, A.; Naughton-Treves, L.; Shelley, V. Longitudinal analysis of attitudes toward wolves. Conserv. Biol. 2013, 27, 315-323. [CrossRef]

31. Doney, E.; Bath, A.; Vaske, J. Understanding conflict and consensus regarding wood bison management in Alaska, USA. Wildl. Res. 2018, 45, 229-236. [CrossRef]

32. Teel, T.L.; Manfredo, M.J. Understanding the diversity of public interests in wildlife conservation. Conserv. Biol. 2010, 24, 128-139. [CrossRef] 
33. Lokocz, E.; Ryan, R.L.; Sadler, A.J. Motivations for land protection and stewardship: Exploring place attachment and rural landscape character in Massachusetts. Landsc. Urban. Plan. 2011, 99, 65-76. [CrossRef]

34. Reimer, A.P.; Thompson, A.W.; Prokopy, L.S. The multi-dimensional nature of environmental attitudes among farmers in Indiana: Implications for conservation adoption. Agric. Hum. Values 2012, 29, 29-40. [CrossRef]

35. Klain, S.C.; Olmsted, P.; Chan, K.M.; Satterfield, T. Relational values resonate broadly and differently than intrinsic or instrumental values, or the New Ecological Paradigm. PLoS ONE 2017, 12, e0183962. [CrossRef]

36. Swartz, T.M. Farm Ponds of the Eastern Great Plains: Key Challenges and Opportunities for Conserving Amphibians in These Novel Ecosystems; University of Illinois at Urbana-Champaign: Urbana, IL, USA, 2018.

37. Miller, J.R.; Morton, L.W.; Engle, D.M.; Debinski, D.M.; Harr, R.N. Nature reserves as catalysts for landscape change. Front. Ecol. Environ. 2012, 10, 144-152. [CrossRef]

38. Morton, L.W.; Regen, E.; Engle, D.M.; Miller, J.R.; Harr, R.N. Perceptions of landowners concerning conservation, grazing, fire, and eastern redcedar management in tallgrass prairie. Rangel. Ecol. Manag. 2010, 63, 645-654. [CrossRef]

39. Raynor, E.J.J.C.J.; Swartz, T.M.; Morton, L.W.; Schacht, W.H.; MIller, J.R. Shifting cattle producer beliefs on stocking and invasive forage: Implications for grassland conservation. Rangel. Ecol. Manag.. (In Review).

40. Coon, J.J.; Morton, L.W.; Miller, J.R. A Survey of Landowners in the Grand River Grasslands: Managing Wildlife, Cattle and Non-Native Plants.; University of Illinois Department of Natural Resources and Environmental Sciences: Urbana, IL, USA, 2018.

41. Dillman, D.A.; Smyth, J.D.; Christian, L.M. Internet, Phone, Mail and Mixed-Mode Surveys: The Tailored Design Method, 4th ed.; John Wiley \& Sons: Hoboken, NJ, USA, 2014; p. 528.

42. Lannoo, M. A fish fry: the role of exotic species and aquacultural practices in producing amphibian declines in the upper Midwest. In Minnesota's Amphibians and Reptiles: Conservation and Status; Moriarty, J.J., Jones, D., Eds.; Serpent's Tale Press: Excelsior, MN, USA, 1996; pp. 25-27.

43. Perry, K.; Jayne, D.; Smith, M.; Branson, A. Missouri Pond Handbook; Missouri Department of Conservation: Jefferson City, MO, USA, 2015; p. 72.

44. Chadde, S.W. A Great Lakes Wetland Flora: A Complete Guide to the Wetland and Aquatic Plants of the Midwest, 4th ed.; CreateSpace Independent Publishing Platform: Scotts Valley, CA, USA, 2012; p. 690.

45. Miklovic, S. Typha Angustifolia Management: Implications for glacial marsh restoration. Restor. Reclam. Rev. 2000, 6, 1-11.

46. Stevens, M.; Hoag, C. Plant. Guide: Broad-Leaved Cattail, Typha Latifolia; U.S. Department of Agriculture Natural Resources Conservation Service: Davis, CA, USA, 2003; pp. 1-2.

47. Stevens, M.; Hoag, C. Plant. Guide: Narrowleaf Cattail, Typha angustifolia L; U.S. Department of Agriculture Natural Resources Conservation Service: Davis, CA, USA, 2006; pp. 1-4.

48. Weller, M. Studies of cattail in relation to management for marsh wildlife. Iowa State J. Res. 1975, 49, $383-412$.

49. Burnham, K.P.; Anderson, D.R. Model. Selection and Multimodel Inference: A Practical Information-Theoretical Approach, 2nd ed.; Springer: New York, NY, USA, 2002; p. 488.

50. Arnold, T.W. Uninformative parameters and model selection using Akaike's Information Criterion. J. Wild. Manag. 2010, 74, 1175-1178. [CrossRef]

51. R Core Team. R: A language and Environment for Statistical Computing; R Foundation for Statistical Computing: Vienna, Austria, 2015.

52. Mazerolle, M.J. AICcmodavg: Model. Selection and Multimodel Inference Based on (Q)AIC(c). R package version 2.1-1. Available online: https://cran.r-project.org/package=AICcmodavg (accessed on 22 August 2019).

53. Bates, D.; Maechler, M.; Bolker, B.M.; Walker, S. Fitting linear mixed-effects models using lme4. J. Stat. Softw. 2015, 67, 1-48. [CrossRef]

54. Coon, J.J.; van Riper, C.J.; Morton, L.W.; Miller, J.R. Assessing non-response bias in a survey conducted in the rural Midwest. (In review)

55. Cowardin, L.M.; Myers, V.I. Remote sensing for identification and classification of wetland vegetation. J. Wildl. Manag. 1974, 38, 308-314. [CrossRef]

56. Bradbury, R.B.; Hill, R.A.; Mason, D.C.; Hinsley, S.A.; Wilson, J.D.; Balzter, H.; Anderson, G.Q.; Whittingham, M.J.; Davenport, I.J.; Bellamy, P.E. Modelling relationships between birds and vegetation structure using airborne LiDAR data: A review with case studies from agricultural and woodland environments. Ibis 2005, 147, 443-452. [CrossRef] 
57. Barrett, W. Frogging in Iowa. Ann. Iowa 1964, 37, 362-365. [CrossRef]

58. Prokopy, L.S.; Floress, K.; Klotthor-Weinkauf, D.; Baumgart-Getz, A. Determinants of agricultural best management practice adoption: Evidence from the literature. J. Soil Water Conserv. 2008, 63, 300-311. [CrossRef]

59. Lutter, S.H.; Dayer, A.A.; Rodewald, A.D.; McNeil, D.J.; Larkin, J.L. Early successional forest management on private lands as a coupled human and natural system. Forests 2019, 10, 499. [CrossRef]

60. Porej, D.; Hetherington, T.E. Designing wetlands for amphibians: The importance of predatory fish and shallow littoral zones in structuring of amphibian communities. Wetl. Ecol. Manag. 2005, 13, 445-455. [CrossRef]

61. Shulse, C.D.; Semlitsch, R.D.; Trauth, K.M.; Gardner, J.E. Testing wetland features to increase amphibian reproductive success and species richness for mitigation and restoration. Ecol. Appl. 2012, 22, 1675-1688. [CrossRef] [PubMed]

62. Joshi, S.; Arano, K.G. Determinants of private forest management decisions: A study on West Virginia NIPF landowners. For. Policy Econ. 2009, 11, 118-125. [CrossRef]

63. Langpap, C. Conservation incentives programs for endangered species: An analysis of landowner participation. Land Econ. 2004, 80, 375-388. [CrossRef]

64. Skelly, D.K. Pond drying, predators, and the distribution of Pseudacris tadpoles. Copeia 1996, 599-605. [CrossRef]

65. Pechmann, J.H.; Scott, D.E.; Gibbons, J.W.; Semlitsch, R.D. Influence of wetland hydroperiod on diversity and abundance of metamorphosing juvenile amphibians. Wetl. Ecol. Manag. 1989, 1, 3-11. [CrossRef]

66. NRCS. Farm Pond Ecosystems; United States Department of Agriculture: Washington, DC, USA, $2006 ;$ p. 12.

67. Huggins, D.; Kastens, J.; Baker, D.; Freeman, C. Conversion of Existing Farm Ponds to Wetlands in Agricultural Landscapes for Mitigation, Land Use Treatment and Conservation with a Perspective Toward Climate Change, No. 189; University of Kansas: Lawrence, KS, USA, June 2017; p. 91.

68. Ribeiro, P.F.; Santos, J.L.; Santana, J.; Reino, L.; Beja, P.; Moreira, F. An applied farming systems approach to infer conservation-relevant agricultural practices for agri-environment policy design. Land Use Policy 2016, 58, 165-172. [CrossRef] 